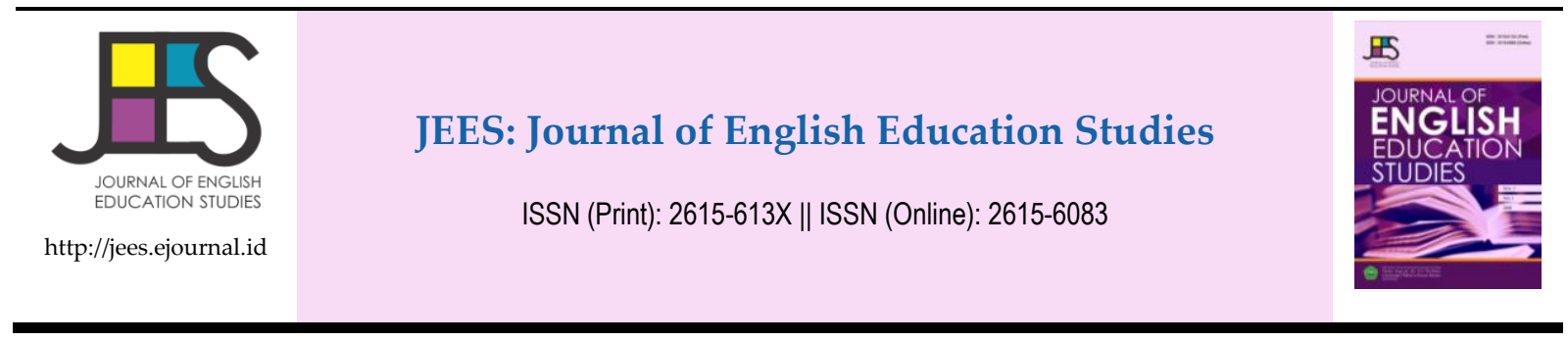

\title{
The Relevance Between An ESP Syllabus And The Students' Needs
}

\author{
Fauzi Miftakh ${ }^{1}$
}

1 Universitas Singaperbangsa Karawang

\begin{tabular}{l} 
ARTICLE INFO \\
\hline Keywords: \\
ESP \\
ESP Syllabus Design \\
Need Analysis \\
Mechanical Engineering
\end{tabular}

\begin{abstract}
In learning English for specific purpose, students sometimes do not get appropriate materials with their needs. ESP materials are more specific than general English, so students should receive materials related to their background of field. This research aimed at finding out the relevance between an ESP syllabus and the students' needs. This research used qualitative method that deals with a single or small-case studied in detail. The population was taken from the 1st semester students of Mechanical Engineering Department at University of Singaperbangsa Karawang. Random sampling was 24 students that was taken from two classes out of 120 students. The data was taken by distributing questionnaire to students and analyzing the syllabus designed by teacher. The result of this research shows that most students who are working in companies need to learn speaking skill as the most important skill as well as grammar. In addition, the ESP syllabus provided by teacher is quite relevant to the students' needs. Therefore, it is suggested that teacher conducts a need analysis to students before designing syllabus, so it can be relevant with the students' needs.
\end{abstract} International License, which permits unrestricted use, distribution, and reproduction in any medium, provided the original work is properly cited. ( 2018 Fauzi Miftakh.

\section{INTRODUCTION}

It is well known by many people that English is now used in many fields for various needs as well. Therefore, English is studied in almost every department in University, at least as a general and specific course. Certainly, the department offers their own aspects and skills of English that based on what is needed. It then leads to establishing the English for specific purpose where the content of English is learned is different among departments. It is supported by Robinson (1980) that the language in an ESP course is not the subject matter, but is being learned as part of the process of acquiring some quite different body of knowledge or set of skills. Therefore, more specifically, ESP emphasizes the special abilities for English language learners than the general English.

However, the skills needed by learners sometimes are not met and served by related institution or more practically it is not listed in the syllabus of the institutions made by teachers or other stakeholders. Richards (2001:33) mentions that different types of students have different language

\footnotetext{
${ }^{1}$ Corresponding author's address: Universitas Singaperbangsa, Karawang, Indonesia e-mail: fauzi.miftakh@staff.unsika.ac.id
} 
needs and what they are taught should be restricted to what they need. Thus, learners should be able to get the material in accordance with what they want because it is usually very useful and will be used in certain circumstances in their environment. Therefore, need analysis is very important to conduct especially for ESP in English as a foreign language.

However, need analysis sometimes is not accurate and do not even have a particular problem. This leads the syllabus created does not meet the criteria of learners' needs. Furthermore, if there is no need analysis, it will give a bad effect to the syllabus presented by the teacher. Though most of the syllabus content itself is taken from the situation and needs in its environment. As pointed out by Dick (2005) that the teaching situation has to be analyzed to reveal the conditions under which the syllabus will be implemented and the available resources, potential problems, as well as external factors that might force us to depart from the syllabus at some point must be determined.

There are still many such problems happen, especially in the university. For example, University of Singaperbangsa Karawang provides variety of departments and faculties. One of them is majoring in mechanical engineering in the faculty of engineering. Surely, English is needed in mechanical engineering and must relate to mechanical engineering itself and focus on the use of language in their field. Thus, in contrast with General English learners, ESP learners are enrolled in the course not for the sake of language knowledge but in order to be able to function in a specific context using the language as a tool (Petrova, 2008:7)

This kind of research has been done by Hossain (2013:22), in his qualitative research. He concluded that students of engineering need to learn Business Communication for use in their future job profession. Focus should be given on both writing business correspondence and speaking skill. It is clear that that the students' need in its institution mostly concerns to the writing and speaking skills. Specifically, those skills will be useful and will be used in their future job profession. Accordingly, Kim (2013) in his research concludes that the most important content in Engineering English chosen by students is daily conversational English (53\%), engineering contents (57\%) and general business English (49\%). In the other hand, the content course is to train people for a job such as work forms, charts and samples of relevant course assignments and student papers; and business communication related websites which provide business letters, dialogues, instructions, telephone conversations, podcasts, etc.

Furthermore, a set of instruction and content of syllabus must depend on students' needs. The contents are developed in a careful process to determine appropriate materials to give to students. Therefore, a type of syllabus is chosen to cover all the contents. These previous research suggested that ESP for engineering students is appropriate to use task-based syllabus, even though there are still other appropriate types. Finally, this study investigates the students' needs in a Mechanical Engineering Department and its relevance to the syllabus provided by the teacher.

Based on the background above, this study attempts to investigate the issue; the appropriateness and relevance of the syllabus to students' needs. The main research questions then formulated into the following lists: 1) What are the students' needs in learning English at Mechanical Engineering Department? 2) Is the syllabus used at Mechanical Engineering Department relevant to the need of students?

\section{ESP}

English for specific purpose (ESP) is the area of English language teaching which focuses on preparing learners "for chosen communicative environments" (Mohan, 1986:15) Additionally, Strevens (1980: 92) concludes that it differs from ESL in that it is based on a close analysis of the learner's communicative needs for a specific occupation or activity, as well as a detailed analysis of the language of that occupation or activity. Hence, the term "chosen communicative environment" means the English language is specifically used in a field. It is used communicatively to support activities that need English as a tool. 
Furthermore, in contrast with English for general purposes, ESP learners usually study English in order to carry out a particular role such as doctors, nurses, engineering and scientist. The current view is that ESP is not a product, but rather a process. For example, Crystal (2003: 108) defines ESP as 'a course whose content is determined by the professional needs of the learner'. A similar idea is expressed by Hutchinson and Waters:

ESP is not a matter of teaching 'specialised varieties' of English. The fact that language is used for a specific purpose does not imply that it is a special form of the language, different in kind to other forms. Certainly, there are some features that can be identified as 'typical' of a particular context of use and which, therefore, the learner is more likely to meet in the target situation. (1987: 19)

Besides, there are some characteristics of ESP that differentiate itself from general English. Evans and John (1997) formulated a modified definition of absolute and variable characteristics of ESP:

1) Absolute Characteristics

- ESP is defined to meet specific needs of the learner;

- ESP makes use of the underlying methodology and activities of the discipline it serves;

- ESP is centered on the language (grammar, lexis, register), skills, discourse and genres appropriate to these activities.

2) Variable Characteristics

- ESP may be related to or designed for specific disciplines;

- ESP may use, in specific teaching situations, a different methodology from that of general English;

- ESP is likely to be designed for adult learners, either at a tertiary level institution or in a professional work situation. It could, however, be for learners at secondary school level;

- ESP is generally designed for intermediate or advanced students;

- Most ESP courses assume some basic knowledge of the language system, but it can be used with beginners.

Thus, a number of terms and phrases are very important for ESP. Those are specific needs, language skills, designed for specific disciplines, and designed for adult learners. It means that ESP program usually given to learners who have good knowledge of general English, or at least they have understood the basic of English.

In addition, Hutchinson \& Waters (1987:3) assert that ESP is based on designing courses to meet learners' needs. Thus, the development of ESP is based on the learners' needs or wants. As stated by Richards (2001:28) The ESP approach to language teaching began as a respond to a number of practical concerns such as:

- The need to prepare growing numbers of non-English background students,

- The need to prepare materials to teach students who already mastered general English, but now needed English for use in employment,

- The need for materials for people needing English for business purposes, and

- The need to teach immigrants the language needed to deal with job situations.

All the practical concerns above have a strong influence to the development of ESP today. In this globalization era, the development of business and information are growing rapidly. Thus, the need of English is urgent since English is used to communicate among people in business and working. Accordingly, ESP Programs are offered in many institutions to meet peoples' needs from different working environments especially for non-native English speakers.

\section{ESP Syllabus Design}

Syllabus Design can be defined into many differences. First off all, syllabus is a subpart of curriculum which is concerned with a specification of what units will be taught (Allen, 1984:64). 
Thus, syllabus is more specific than curriculum that has specific content. As added by Hutchinson and Waters (1987: 94), syllabus can be classified in terms of the underlying approach to the course design. They all refer to a process which includes many some factors such as learners, their needs, materials, etc. In other words, there are different roles a syllabus could play in this process. (Petrova: 2013:29) explain that firstly the syllabus is the 'prime generator' of the course contents in a languagecentred approach, where everything throughout the course happens according to the syllabus. Secondly, it is 'to provide opportunities for learners to employ and evaluate the skills and strategies considered necessary in the target situation'

Yalden (1987:86) advocates that a syllabus is an instrument to link learners' needs and aims to activities that take place in the classroom. While Hutchinson and Waters (1987: 94) more added that the content of a syllabus depends on two factors: the actual learning situation and the target situation. Subsequently, a good syllabus should accommodate the needs of different students depend on learning situation and target situation. In the other word, syllabus is not developed by teacher without gaining information about specific students' needs. In addition, Syllabus Design in ESP is an even more requiring task because it is dealing with specific learners' needs, specific materials, and specific objectives (Krarzia, 2013:36).

Furthermore, Kranhke (1987: 9) formulated six types of syllabuses for foreign language teaching: Structural syllabus, Notional/Functional syllabus, situational syllabus, Skills-based syllabus, Taskbased syllabus and content-based syllabus. Among those types of syllabus, there are syllabuses as well as integrated syllabuses that can be used as ESP syllabus since the contents concerns to the communicative needs and specific skills to master by learners. For example, to some degree, skillbased syllabus has been used in language for specific purposes (LSP) programs, for learners who have some more or less well-defined activity they need to carry out in the second language. (Kranhke, 1987: 51)

Finally, ESP syllabus must be flexible and it reflects various aspects. This can be organized around different aspects like the subject, structure, notion, skill or learning tasks. However, it does not mean that other aspects that are undervalued or not presented in the course at all. The syllabus must be oriented towards the end of some, or product. At the same time it should not underestimate the importance of experiential learning, or with the process.

\section{Need Analysis in ESP}

It has been widely discussed in the previous section, and as stated by Nunan and Lamb (1996: 27), a syllabus compilation is necessarily preceded by a needs analysis, as it 'provides a basis for setting goals and objectives'. In addition, Richards (2001:32) pointed out that an important principle of ESP approaches to language teaching is that the purposes for which a learner needs a language rather than a syllabus reflecting the structure of general English should be used in planning an English course. In the other words, ESP approach is based on the needs and students' want toward specific English skill, not to the syllabus that has been formed from general English materials. Richards (2001:32) expressed that rather than developing a course around an analysis of the language, an ESP approach starts instead with an analysis of learners' need.

Additionally, Hutchinson and Waters (1987:53) added that what distinguish ESP from General English is not the existence a need as such but rather an awareness of the need. Thus, the awareness will have an influence towards the content in language course when learners and teachers know why the learners need English. Therefore, started from the awareness of a need, teachers and stakeholders then conduct need analysis to learners in order to create compatibility of needs between teachers and learners in terms of content that provided including in the syllabus. Therefore, what is meant by needs analysis here is ultimately the analysis of the target situation needs - the kind of language that the learners have to acquire to cope in the target situation (Hutchinson and Waters, 1987: 54) 
This part of needs analysis is generally referred to as present situation analysis (Evans 2001: 133). Hence, it is possible that an analysis is done not only one time for a period time. It means there must be present analysis for different situation including different learners to anticipate different needs. Moreover, there are various techniques available for gathering information of needs from learners. Tudor (1996: 73) suggested techniques that divided into two types:

1) The source of information is the learners themselves: questionnaires, interviews, tests, participatory needs analysis

2) Information is derived from the target situation analysis: observations, case studies, authentic data collection.

In addition, Hutchinson and Waters (1987: 56-62) formulated a framework for analyzing learning needs that can be used for target situation analysis. It is divided into objective needs and subjective needs.

1) Objective needs

- Why is the language needed?

- How will the language be used?

- What will the content areas be?

- Who will the learners use the language with?

- Where will the language be used?

- When will the language be used?

2) Subjective needs

- Why are the learners taking the course?

- How do the learners learn?

- What resources are available?

- Who are the learners?

- Where will the ESP course take place?

- When will the ESP course take place?

In conclusion, based on the understanding of the need analysis as well as techniques and frameworks in the analysis of learners' needs above, we can just carry out need analysis well and systematically, and then make it as a reference to the development of syllabus that contains the content that is appropriate for the learners.

\section{METHOD}

The method of this research is qualitative design by employing case study. According to Silverman (2005:126), case study examines a case only to provide insight into an issue. Particularly, this study deals with a single or small-case that studied in detail (Silverman, 2005:126). In this study, the researcher investigated the students' perspectives towards their needs in learning English as specific purpose. Besides, the researcher also focused on analyzing a syllabus that used by teacher whether or not it is relevant to the students' needs. This research took the population from the $1^{\text {st }}$ semester students of Mechanical Engineering at University of Singaperbangsa Karawang. The total population is about 120 students. The samples are 24 students that taken randomly from two classes. Those students were chosen because they are also working in companies with different roles.

The instruments of this research used in this study were questionnaire interview guideline, and document analysis. The first, questionnaire was given to selected students. The list of questions was adopted from questionnaire that used by Petrova (2008) in her research. In addition, the questions made were also based on the framework for analyzing learning needs formulated by Hutchinson and Waters (1987: 56-62). The second, interview guideline that relate to the questionnaire was used to ask students about more deeply. The third, document analysis was used to analyze a syllabus made by a teacher who teaches English for Mechanical Engineering 1 for in the first semester 
students. The syllabus consists of 14 meetings. The syllabus was analyzed and described in terms of its relevance to the needs of learners.

\section{Questionnaire}

As stated before, the questionnaire is based on Needs Analysis Framework formulated by Hutchinson and Waters (1987: 56-62) that contains objective and subjective needs. This questionnaire consists of ten closed-ended questions that divided into two parts. Part I (questions 1-4) the respondents were instructed to provide some personal details such as their speciality, age, sex, native language and level of English. In addition, the respondents were asked to state whether they currently have to use English in their job or studies and to assess the amount of specialist knowledge acquired so far.

While in Part 2 (questions 5-11) was aimed at revealing the students' attitude to ESP, as well as their expectations of the course. The questions were meant for measuring the initial level of students' motivation for devoting their time to the subject, and concentrate on three separate aspects: interest, importance in comparison with other subjects and usefulness. The other questions were multiplechoice questions with three to five available options that concern to the four skills of English that is reading, writing, listening and speaking.

The questionnaires were in Bahasa Indonesia distributed directly to the students after finishing during their English lesson by their English teacher. They were allowed to ask questions for clarification if necessary and were given help with formulating their ideas in open-ended questions.

\section{Interview}

Two students were chosen purposively based on their ability of English. The researcher took students who are good and low in English. It was done after the researcher distributed the questionnaire and knew their ability from the questionnaire. The researcher considered those two students could be representative for the other students. Furthermore, structured interview guidelines had been prepared to give to students and the interview was done in Bahasa Indonesia in order to get more comprehensive and understanding data.

\section{Document analysis}

In document analysis, an ESP syllabus made by a teacher who teaches English for Mechanical Engineering 1 for the first semester students of Mechanical Engineering is the main document to analyze. The syllabus consists of 14 meetings of learning and 2 meetings of examinations. The researcher analyzed the syllabus only focused on the topic that provided by teacher in every meeting. After that, the topics were compared to the learners' need that had been obtained by need analysis. Furthermore, the final analysis was to find the relevance of topics in the syllabus to the needs of learners.

The data of this research were analyzed through qualitative data analysis. Having obtained the data from distributing questionnaire, conducting interview and document analysis (syllabus), the researcher immediately analyzed the data. All data were analyzed on the basis of research questions stated in section 1 and were classified into two parts. First, students' needs in learning English which cover the importance of objective and subjective needs as well as the sub skills in the four language skills. The second, the relevance of students' need to syllabus provided. Furthermore, data from questionnaire, interview and documents were analyzed to answer the research questions concerning students' needs of English lesson and the relevance syllabus provided to students based on theory in section II.

In addition, Miles and Huberman (1994) formulated the analysis of qualitative data into activities that is data reduction, data display, and drawing and verifying conclusion. The first, in data reduction step, the researcher collected the data from the questionnaire. There was a large number of data that collected, so the researcher reduced the data to take the more important data and 
deleting the useless data. Thus, the most data taken was the data or answers mostly chosen by students that close to the main needs of students.

The second, Miles and Huberman (1994) pointed out that data display is an organized and compressed assembly of information, so that it can be seen a large amount of data at once, begin to understand what is happening, and start to draw justified conclusions. The data display in this research was matrices that shown in table where the column and row were based on the questionnaires and answers from the students. The third is drawing and verifying conclusion. In this step the researcher made a conclusion from the data display of students' answers as well as the content of syllabus. The conclusion was obtained after carefully comparing and matching the relevance between the students' need that got from data display and the topic of lesson in the syllabus.

\section{RESULT AND DISCUSSION}

From the data collection through the questionnaire, interview and document analysis, the presented data was based on the research questions concerned with the primary data. These findings will be presented in qualitative analysis. In then earlier stage, the researcher pointed out the research question; 1) What are the students' needs in learning English at Mechanical Engineering Department? and 2) What relevance does the syllabus at Mechanical Engineering Department relevant to the need of students? Thus, to answer the first research question, the researcher analyzed data result that obtained from questionnaire that divided into three parts. The first part is about the students' personal information, the second part is about students' attitude towards ESP and the third part was about students' expectations towards ESP course. The student' answers from interview were also analyzed as addition for more comprehensive data. The last, to answer the second research question, the researcher matched and compare the data got from need analysis and syllabus from teacher. It is discussed in the fourth part that is the relevance between students' needs and the content of syllabus.

\section{Students' personal information}

To answer this first part, the researcher firstly analyzed data from questionnaire (Question 1-4). The data can be seen in the table 1 in appendix. Based on the table, it can be concluded that overall, 24 students completed the questionnaire. All their specialties are engineering with native language is Indonesian. Besides, of the students 23 was male and 1 was female with various age from the youngest was 18 years old and the oldest was 40 years old. Furthermore, the level of English was mostly elementary including 18 students while the other 6 students were in the level of pre intermediate and intermediate. In addition, most students already had to use English in their jobs or studies to a greater or lesser extent. 7 students used English from time to time, 12 students used English seldom and 5 students never used English. The last, 10 students were confident enough to assess the amount of their knowledge as substantial, 9 students believed that they had acquired the basics of their main field of study and 5 students felt that they did not know much about their specialty yet.

In line with the data above, it can be concluded that most students have already known English but only the basic or elementary, but in the company they are working, they use English in some kinds of activities especially for those who are expert in their specialty. It is also stated by students through interview that they used English especially to read the instruction of using some tools despite it is rarely used in their activities. Therefore, learning ESP is important for them since their native language is Indonesian and they must improve their skills of English to have better use in their working activities. Meanwhile, the skills of English that they needed are discussed in the next section by answering the other questions of questionnaire. 


\section{Students' attitude towards ESP course}

To answer this part, the researcher firstly analyzed data from questionnaire (Question 5-8). The data can be seen in the table 2 (see appendix). By seeing the table, most students (21 students) expressed an overall interest in taking ESP with only 3 students answering that they were not very much interested in the course. Besides, 13 students considered it as important as other subjects and 7 students felt that it was more important than other subjects in the college. However, only 4 students rated it as a less important subject in their study programs. In addition, most students (16 students) regarded ESP as a very useful course. While, the rest of 8 students thought that it could be useful for them in the future. In addition, from the interview, students said that at least they can improve their ability of English and they considered that English is important even it is specifically talking about mechanical engineering.

Furthermore, the answers of students for the question 8 that focused on the areas where ESP might be of use, all students thought that the four aspects provided in the questions were useful. To the question whether ESP will be useful for using materials written in English related to the students' specialty, 19 students answered "very useful" while the other 5 students answered "useful". In the next question 17 students thought ESP would be very useful for finding a better job and 7 students thought it was useful. Furthermore, 11 students stated that ESP would be very useful for communication with specialists from other countries while 8 students stated it was useful for that purpose. Finally, most students (22 students) felt that ESP would be useful in improving their general language skills, while 2 other responded that it was useful only.

\section{Students' expectations towards ESP course}

To answer this third part, the researcher analyzed data from questionnaire (Question 9) that consist of 7 sub questions concerning the purpose of ESP in improving skills of English. The data can be seen in the table 7. Concerning the students' expectations of ESP, the purpose to learn professional English terminology was considered important component of the course by 6 students. 15 students agreed that it would be useful for them. Only 1 person claimed that they already knew all the necessary terminology. Furthermore, 12 students answered that they needed to study different topics related to their specialty. Only 7 students rated it as important for an ESP course. On the other hand, to improve grammar was thought to be important by 20 students and useful by 4 students.

In addition, according to the students' answers, the language skills considered the most important skill was speaking that chosen by 22 students. Next comes the development of writing skills with 20 students considering those the most important. The reading skill considered as the most important thing by 19 students and listening skills by 16 students. However, it is actually complicated when considering student is interested in both mastering communication and grammar. As added by students in interview, they want to be able to speak in English but they also want to master in grammar. Consequently, it will make teacher gets confused in choosing method to use as well as to design the syllabus whether communicative or structural approach.

After that, the students' perspective of the way class work should be organized is reflected in the table 4 (see appendix). As the table shows, the most preferred forms of work chosen by most students (15 students) were teacher-oriented lessons, where the teacher explains some new material and then corrects students' mistakes when they practice. Students also added that they tend to be reluctant in doing presentation and discussion since their ability in speaking is still bad. Furthermore, there are two ways that have the same amount of highest rankings, those are analyzing language structures (8 students) and trying to work with new words on students' own and learning by using songs, films, games, projects and presentations (7 students). The last effective ways according to students was class discussions, role-plays/group work where students are given occasion for discussions, role-plays and group work (5 students). 


\section{The relevance between students' needs and the content of syllabus}

This is the last part of analyzing the data where the researcher compared and matched the two data obtained, students' needs and the syllabus content. Based on the need analysis, it can be concluded most students who are mostly still in elementary level of English, need to learn speaking skill as the most important skill and writing as the second one. In addition, they also considered that grammar is also important to learn. Besides, the most preferred forms of work were teacher-oriented lessons, where the teacher explains some new material and then corrects students' mistakes when they practice, and learning by using songs, films, games, projects and presentations as the second one. Hence, to compare with the syllabus content, the researcher provided the syllabus.

Based on the syllabus, it can be seen that the skill offers to learn by students is mostly speaking skill. This skill is emphasized and it can be applied in some meeting that is $1,3,5$. In these meeting, students are instructed to speak related to the topic such as introducing themselves (meeting 1), daily activity (meeting 3 ) and what will you do as a mechanical engineering (meeting 5). While in the meeting $12,13,14$, and 15 , the students must speak to present the material that has been discussed in each group. It is in accordance with the purpose of course that stated in the beginning that the students are encouraged to express their ideas by using English with the theme of mechanical engineering by presentation. Thus, this aspect is appropriate with the students' need that speaking skill is the most wanted skill by students in need analysis. However, the students' needs in writing skill can be applied in the meeting 2, 3, 6 and 9 where students will have some practices in writing different texts.

Furthermore, based on the students' need, students considered that grammar is important to learn. When we see the syllabus, there are some meetings that focus on grammar material that is in meeting 4. Grammar is also taught in every meeting especially in writing like stated in the description of syllabus purpose "in writing, students are encouraged to learn grammar actively. However, the portion probably is not as much as in general English. Thus the needs of students in Grammar seems difficult to ne provided by teachers completely. Thus, it can be concluded that between the students' need in grammar and the syllabus is quite relevant although the learning focus is on the skill as well as communicative approach, not to the form as well as grammar since there are not many meetings that focuses on grammar.

Additionally, based on the need analysis, the most preferred forms of work were teacher-oriented lessons, where the teacher explains some new material and then corrects students' mistakes when they practice. In the syllabus, it is not clearly stated in every meeting what actually the role of teacher during the teaching process. However, it is explained in the learning strategies that in the teaching process, teacher firstly gives the theory and materials followed by students' practice in the class. Specifically, it can be applied in the meeting 1, 2, 3, 4, 5, 6, 7, 9 and 10 where the teacher probably gives explanations firstly, then students do the practice. In the other hand, learning by using songs, films, games, projects and presentations can be done in meeting 12-15 where students become presenters.

\section{CONCLUSION}

From the finding and discussion and based on the research questions, there are some conclusions that can be taken. The first, most students are very interested in learning English as well as general and specific purposes since their level in English is still elementary. The second, most students also work in some companies that require them to use English, so they considered that they need to learn speaking skill as the most important skill and writing as the second one beside they need to learn grammar as well. The third, the most preferred forms of work based on the students' need were teacher-oriented lessons where the teacher explains some new materials and then corrects students' mistakes when they practice. Learning by using songs, films, games, projects and presentations also can be various techniques to make students interested in learning English. The last is that ESP 
syllabus provided by teacher is quite relevant to the students' needs in. It can be seen that speaking skill becomes the main skill that offered by teacher as well as the skill that needed by students. In addition, the students' need of grammar is also provided by teacher in every meeting but in a small portion since ESP tends to the students' communicative ability rather than grammar.

In addition, the researcher suggests some recommendations that it is be better for teacher to conduct need analysis to students before developing an ESP syllabus. Teacher should carefully consider what kind of syllabus they will develop because students sometimes want to master both communicative and grammar, so teacher should use appropriate syllabus whether communicative or structural approach. In participating in ESP class, students need to have basic general English in order to study effectively since the materials they are taught is relatively difficult than general English. The last, for further research, it can be included all aspects of analysis to have more valid and accurate result. Since in this research, there only involves syllabus and the instrumentations was only questionnaire and interview with a few students.

\section{REFERENCES}

Allen, J. P. B. (1984). General Purpose Language Teaching: A Variable Focus Approach. Cambridge: Cambridge University Press.

Crystal, D. (2003). The Cambridge Encyclopedia of the English Language. 2nd ed. Cambridge: Cambridge University Press.

Dick, L. (2005). Syllabus writing. Teaching English. Available at http://www.teachingenglish.org.uk/think/methodology/syllabus.shtml.

Evans, D. and M.J. St. John. (1997). Developments in ESP: A Multidisciplinary Approach, Cambridge: Cambridge U. P.

Hossain, J. (2013). ESP Needs Analysis for Engineering Students: A Learner Centered Approach. Presidency University.

Hutchinson, T. and Waters, A. (1987). English for Specific Purposes: A Learning-centred approach. Cambridge: Cambridge University Press.

Kim, Hyun Hyo. (2013). A Research on the English for Engineering Students Course Based on Needs Analysis in Korea. Kongju National University.

Krahnke, K. (1987). Approaches to Syllabus Design for Foreign Language Teaching. New Jersey: Englewood Cliffs.

Krarzia, N. (2013). Designing a Syllabus for ESP Learners: The Case of $2^{\text {nd }}$ Year Commercial Sciences' Students. University of Constantine.

Miles, M.B., \& Huberman, M.A. (1994). Qualitative Analysis: An Expanded Sourcebook. Thousand Oaks, CA: Sage.

Mohan, B. (1986). Language and content. Reading, MA: Addison-Weasley.

Nunan, D. and Lamb, C. (1996). The Self-directed Teacher: Managing the Learning Process. Cambridge: Cambridge University Press.

Petrova, I. (2008). Needs Analysis as a Starting Point for Designing a syllabus for English for Specific Purposes Courses. Tartu University.

Richards, Jack C. (2001). Curriculum Development in Language Teaching. Cambridge: Cambridge University Press.

Robinson, P. (1980). ESP: English for specific purposes. Oxford: Pergamon Press. 
Silverman, D. (2005). Doing Qualitative Research, Writing a Research Proposal. London: Sage.

Strevens, P. (1980). Teaching English as an International language: From practice to principle. Oxford: Pergamon Press.

Tudor, I. (1996). Learner-centredness as Language Education. Cambridge: Cambridge University Press.

Yalden, J. (1987). Principles of Course Design for Language Teaching. Cambridge: Cambridge University Press. 